\title{
PERANAN PENDIDIKAN AGAMA ISLAM DALAM MEMBENTUK SIKAP TAQWA ANAK DI SEKOLAH DASAR
}

\author{
Muh. Arif K. \\ UPP PGSD Bone Fakultas Ilmu Pendidikan UNM \\ muh.arif.k@unm.ac.id
}

\begin{abstract}
ABSTRAK
Peranan pendidikan agama Islam dalam membentuk sikap taqwa pada anak di sekolah dasar, pada dasarnya diperlukan kesadaran, penghayatan serta pengalaman dari beberapa unsur yang bertalian dengan isi pendidikan agama Islam mengandung keimanan, amaliah, ilmiah, dam pendidikan tentang akhlakul karimah sebagai wujud akibat dari pendidikan agama Islam dengan berfokus unsurunsur obyek kajian tersebut di atas. Pendidikan dalam arti umum mencakup segala usaha dan perbuatan dari generasi tua untuk mengalihkan pengalamannya, pengetahuannya, kecakapannya serta keterampilannya kepada generasi muda untuk memungkinkan melakukan fungsi hidupnya dalam pergaulan bersama, dengan sebaik-baiknya. "Pendidikan nasional berdasarkan pada Pancasila, bertujuan untuk meningkatkan ketaqwaan terhadapa Tuhan Yang Maha Esa, kecerdasan dan keterampilan, mempertinggi budi pekerti, memperkuat kepribadian, dan mempertebal semangat kebangsaan dan cinta tanah air, agar dapat menumbuhkan manusia-manusia pembangunan yang dapat membangun dirinya sendiri serta bersama-sama bertanggung jawab atas pembangunan bangsa”.
\end{abstract}

Kata kunci: Pendidikan agama Islam, peran dan sikap taqwa

\section{PENDAHULUAN}

Pendidikan agama Islam merupakan kebutuhan penting bagi setiap umat Islam. Sebab muslim dapat mengarahkan diri menuju ke jalan yang benar dan menyebabkan diri selamat dunia dan akhirat, sebagai akibat dari sekian banyak ibadah yang telah dilakukan. Oleh karena itu, pendidikan agama Islam memiliki peranan penting dalam mengarahkan, mengingatkan dan memotivasi umat muslim untuk selalu belajar dari sekian banyak ajaran yang harus dipahami dan diamalkan sebagai bekal menghadapi hari pembalasan.

Sehubungan dengan itu, perlu dijelaskan bahwa pendidikan adalah bagian dari suatu proses yang diharapkan untuk mencapai suatu tujuan (Hamdani Ihsan dkk, 2001: 59).

Selain itu, Harahap (dalam Psikologi Pendidikan, Muhibbin Syah, 1996:11) dijelaskan bahwa

"Pendidikan adalah usaha secara sengaja dari orang dewasa untuk dengan pengaruhnya meningkatkan si anak kekedewasaan yang selalu diartikan mampu menimbulkan tanggung jawab moril dari segala perbuatannya. Orang dewasa itu adalah orang tua si anak atau orang yang atas dasar tugas dan kedudukannya mempunyai kewajiban untuk mendidik, misalnya guru sekolah, pendeta atau kiai dalam lingkungan keagamaan, kepala-kepala asrama dan sebagainya.

Dengan berdasarkan pengertian pendidikan tersebut, maka pendidikan Islam itu pada dasarnya adalah merupakan upaya pembiasaan dan pengembangan potensi manusia agar tujuan kehadirannya di dunia ini sebagai hamba Allah SWT dan sekaligus sebagai khalifah, dengan harapan mendapat berkah dan berhasil sebaik mungkin. Potensi yang dimaksud meliputi potensi jasmani dan rohani seperti, akal, perasaan, kehendak dan aspek rohaniah lainnya.

Sekaitan dengan itu, pendidikan agama Islam dimaksudkan meliputi keseluruhan ajaran Islam yang terpadu dalam keimanan serta ibadah dan muamalah yang implikasinya mempengaruhi proses berpikir, merasa, berbuat dan terbentuk kepribadian yang pada gilirannya terwujud dalam akhlakul karimah salah satu wujud kebahagiaan.

Pendidikan agama Islam diharapkan dapat berperan penting sebagai filter terhadap kemungkinan timbulnya dampak negatif dari akibat kemajuan ilmu pengetahuan dan teknologi yang berkembang cepat dimasa sekarang ini. 
Sehubungan denga uraian tersebut, maka Zakiah Daradjat dkk, (1984: 310) menjelaskan bahwa pendidikan Islam ialah suatu proses pembentukan pribadi maupun masyarakat muslim (Culturalisasi civilisasi). Memahami pengertian tersebut, maka hakekat pendidikan terutama pendidikan agama Islam menghendaki keseluruhan rohani, keutamaan jiwa, kemuliaan akhlak dan kepribadian yang kuat, merupakan utama dalam mewujudkan suatu sikap taqwa kepada Allah SWT, dan sekaligus menimbulkan suatu kebahagiaan hidup di dunia dan di akhirat.

Sehubungan dengan itu, Agustani (2006: 8) mengemukakan bahwa taqwa merupakan sikap batin dan perilaku seseorang untuk tetap konsisten melaksanakan perintah Allah SWT dan menjauhi segala larangannya.

Memperhatikan dari pengertian dan harapan, baik yang berhubungan dengan pendidikan agama Islam terhadap sikap taqwa hendaknya kita selalu berusaha meningkatkan sikap taqwa melalui pendidikan agama Islam baik secara formal maupun non formal.

Oleh karena itu, penulis berkeyakinan bahwa mantapnya peranan pendidikan agama Islam dan prilaku atau sikap taqwa akan mantap pula kegiatan keagamaan sebagaimana harapan ajaran agama Islam.

Namun, kenyataannya harapan itu belum dapat terlaksana secara memadai dan dapat dibuktikan bahwa masih sering ditemukan sebahagian umat Islam kurang memperhatikan hal-hal yang perlu dilaksanakan, sesuai ajaran pendidikan agama Islam, masih sering ditemukan anak di sekolah dasar kurang meminati pelajaran pendidikan agama Islam, masih ditemukan umat Islam terutama dikalangan anak di sekolah dasar kurang memahami cara membaca Al Qur'an sebagai petunjuk, pedomannya untuk menjalankan hasil usaha guru pendidikan agama Islam.

Dengan memperhatikan berbagai fenomena yang ada tersebut di atas, maka penulis mendapat perhatian untuk menguraikan persoalan tersebut dalam bentuk karya tulis ilmiah yang berjudul "Peranan Pendidikan Agama Islam Dalam Membentuk Sikap Taqwa Anak di Sekolah Dasar”.

Berdasarkan dari uraian latar belakang tersebut di atas, maka penulis dapat mengemukakan suatu masalah yaitu: "Bagaimana peranan pendidikan agama Islam dalam membentuk sikap taqwa anak di sekolah dasar".

\section{PEMBAHASAN}

A. Pengertian

Untuk memperjelas uraian variabel dalam judul makalah ini, maka penulis menguraikan pengertian pendidikan agama Islam dan sikap taqwa.

\section{a. Pendidikan Agama Islam}

Untuk mengetahui hakekat pendidikan agama Islam maka terlebih dahulu penulis memberikan pengertian kata demi kata. Pendidikan menurut Syaiful Bahri Djamarah (1997: 22) adalah usaha sadar dan bertujuan untuk mengembangkan kualitas manusia, sebagai suatu kegiatan yang sadar akan tujuan, maka dalam pelaksanaannya berada dalam proses yang berkesinambungan dalam setiap jenis dan jenjang pendidikan. Semua itu berkaitan dalam suatu sistem pendidikan yang itegral.

Selain itu, Ahmad Tafsir (1998: 6) mengemukakan bahwa pendidikan adalah usaha meningkatkan diri dalam segala aspeknya. Maksud dari pengertian ini adalah mencakup kegiatan pendidikan yang melibatkan guru (pendidik), atau mencakup pendidikan formal, maupun nonformal serta informal.

Menurut Ahmad Tafsir (1998: 26) bahwa pendidikan ialah pengembangan pribadi dalam semua aspeknya. Dengan penjelasan bahwa yang dimaksud pengembangan pribadi ialah yang mencakup pendidikan oleh diri sendiri, pendidikan oleh lingkungan, dan pendidikan oleh orang lain (guru), seluruh aspek yaitu mencakup jasmani, akal dan hati.
Hamdani Ali
(1986:
8) juga

berpendapat bahwa:

Pendidikan dalam arti umum mencakup segala usaha dan perubahan dari generasi tua untuk mengalihkan pengalamannya, pengetahuannya, kecakapannya serta keterampilannya pada generasi muda untuk memungkinkan melakukan fungsi hidupnya dalam pergaulan bersama, dengan sebaik-baiknya.

Karena itu, corak pendidikan itu erat hubungannya dengan corak penghidupan, karenanya jika corak penghidupan itu berubah, berubah pulalah corak pendidikannya, agar si anak siap untuk memasuki lapangan penghidupan itu. Pendidikan merupakan suatu displin dari berbagai macam bagian komponen.

Terkait dari uraian tersebut, maka Zakiah Daradjat (1984: 27) menjelaskan bahwa pendidikan agama Islam ialah usaha 
kegiatan yang dilakukan oleh pendidik untuk membentuk manusia yang berkepribadian baik.

\section{b. Taqwa}

Taqwa adalah terpeliharanya sifat diri untuk tetap taat melaksanakan perintah Allah dan menjauhi segala larangan-Nya atau keinsafan yang diikuti kepatuhan dan ketaatan dalam melaksanakan perintah Allah dan menjauhi segala larangan-Nya (Kamus Besar Bahasa Indonesia, 1993: 999).

Berdasarkan pengertian tersebut, maka dipahami bahwa takut akan Allah ialah mempunyai perasaan takut akan Allah lantaran sesuatu kesalahan yang telah kita lakukan, atau boleh jadi telah kita lakukan, yakni takut akan mendapat azab-Nya dan siksa murka-Nya.

Dengan demikian, pengertian takut tersebut terdapat dua hal dipahami bahwa ada yang menyangkut takut akan Allah yakni dapat dicapai oleh mereka yang mempunyai jiwa yang sejahtera, iktikad yang khalisk bersih dan mempunyai penglihatan mata hati yang teguh, menyelami rahasia-rahasia sifat Allah yang Maha Esa dan Maha Kuasa yang dengan demikian, terpangpanglah kehebatan Allah dipenglihatannya dan hiduplah rasa takut kepada Allah.

Kedua dicapai oleh umat manusia. Tiap-tiap manusia dapat memperoleh derajat ini apabila ia telah percaya benar akan adanya syurga dan negara, percaya benar kepada pembalasan akhirat. Oleh karenanya, hendaklah kita menghidupkan dengan sehiduphidupnya rasa takut akan Allah, rasa takut akan azab-Nya yang sangat pedih dan sangat keras, walaupun kita merasa bahwa kita tidak merasa bersalah apa-apa.

Terkait dari uraian itu, Suyuti (1994:20) mengatakan bahwa taqwa adalah tingkat kualitas yang paling tinggi yang dicapai oleh manusia sehingga perbuatan taqwa akan dapat menggambarkan kepribadian dan tingkah laku yang ideal dari seseorang di dalam penghambaannya kepada Allah, juga dalam pergaulan sesama manusia.

\section{B. Tujuan Pendidikan}

Tujuan pendidikan sebenarnya itu ditentukan oleh zaman dan kebudayaannya di tempat kita hidup.

Setiap upaya guru dalam proses pendidikan diatur oleh tujuan tertentu, apapun jenis tujuan itu. Kejelasan tujuan yang dilihat pada rumusan dan definisinya berpengaruh terhadap kemungkinan keberhasilan pencapaiannya. Banyak tujuan yang dirumuskan secara umum dan samar, seperti pendidikan utnuk hidup. Tujuan semacam ini dapat diterima, karena setiap pendidikan mesti mempersiapkan peserta didik untuk hidup.

Salah satu tujuan umum yang berkaitan dengan pendidikan sepanjang hayat ialah tujuan "pendidikan akhlak" yang mengarah kepada sikap taqwa. Pembicaraan tentang akhlak yang mulia (taqwa) tanpa kesepakatan tentang isi kata-kata itu tidak akan bermakna. Oleh sebab itu, diperlukan pembatasan terhadap norma-norma akhlak sesuai dengan pandangan sosial keagamaan tertentu.

Ngalim (2002: 20) mengemukakan tujuan umum ialah tujuan di dalam pendidikan yang seharusnya menjadi tujuan orang tua atau pendidik lain, yang telah ditetapkan oleh pendidik dan selalu dihubungkan dengan kenyataan yang terdapat pada anak didik itu sendiri dan dihubungkan dengan syarat-syarat dan alat-alat untuk mencapai tujuan umum.

Tujuan umum itu tidak akan selalu diingat oleh si pendidik dalam melaksanakan pendidikannya. Oleh karena itulah, tujuan umum itu selalu dilaksanakan dalam bentukbentuk yang khusus mengingat keadaankeadaan dan faktor-faktor yang terdapat pada anak sendiri.

Tujuan pendidikan menurut Dewi dalam buku Ilmu Pendidikan (Ngalim, 2002: 24) adalah: membentuk manusia untuk menjadi warga negara yang baik. Untuk itu, di sekolah-sekolah diajarkan segala sesuatu kepada anak yang perlu dibagi kehidupannya dalam masyarakat, sebagai anggota masyarakat dan sebagai warga negara.

Terkait dengan tujuan pendidikan tersebut, maka di dalam GBHN 1983 - 1988 tujuan pendidikan dinyatakan sebagai berikut:

"Pendidikan nasional berdasarkan Pancasila, bertujuan meningkatkan ketaqwaan terhadap Tuhan Yang Maha Esa, kecerdasan dan keterampilan, mempertinggi budi pekerti memperkuat kepribadian, dan mempertebal semangat kebangsaan dan cinta tanah air, agar dapat menumbuhkan manusia-manusia pembangunan yang dapat membangun dirinya sendiri serta bersama-sama bertanggung jawab atas pembangunan bangsa".

Memperhatikan dari sekian tujuan pendidikan secara umum, maka dapat pula dikemukakan tujuan pendidikan agama Islam 
bahwa pendidikan menurut pasal 1 UndangUndang No. 2 Tahun 1989 adalah "usaha sadar untuk menyiapkan peserta didik melalui kegiatan bimbingan, pengajaran dalam atau latihan bagi peranannya dimasa yang akan datang".

Dilihat dari satuan penyelenggaraan kegiatan belajar mengajar dilaksanakan di sekolah dan di luar sekolah. Jalur pendidikan sekolah merupakan pendidikan yang diselenggarakan secara berjenjang dan berkesinambungan yang dibedakan dengan jalur pendidikan luar sekolah, yakni tidak berjenjang dan tidak berkesinambungan seperti pendidikan dalam keluarga, kelompok belajar dan kursus-kursus.

Oleh karena itu, perlu dipahami bahwa tujuan pendidikan agama Islam, sebab pendidikan Islam berhubungan erat dengan agama Islam itu sendiri, lengkap dengan aqidah, syariah dan sistem kehidupannya. Keduanya ibarat dua kendaraan yang berjalan di atas dua jalur seimbang, baik dari segi tujuan maupun rambu-rambunya yang disyariatkan bagi hamba Allah yang membekali diri dengan taqwa, ilmu hidayah, serta akhlak untuk menempuh perjalanan hidup.

Manurut Syafi'i (2001: 6) bahwa tujuan pendidikan agama Islam adalah menumbuhkan keseimbangan kepribadian manusia melalui latihan spiritual, intelektual, rasional, perasaan dan kepekaan.

Berdasarkan dari uraian tujuan pendidikan agama Islam tersebut, maka dipahami bahwa hendaknya tujuan pendidikan Islam itu adalah yang baik, atau dengan kata lain bahwa menghendaki tujuan akhir pendidikan Islam yaitu manusia berakhlak mulia. Dan orang berakhlak mulai disebut juga sebagai sikap taqwa kepada Allah SWT.

\section{Isi Pendidikan Agama Islam}

Karakteristik isi pendidikan agama Islam pertama-tama tampak pada kriteria pilihannya yaitu iman, ilmu, akhlak dan sosial. Dengan kriteria tersebut pendidikan agama Islam merupakan pendidikan keimanan, ilmiah, amaliah, moral dan sosial. Semua kriteria tersebut terhimpun dalam firman Allah SWT ketika menyifati kerugian manusia yang menyimpang dari jalan pendidikan agama Islam, baik manusia sebagai individu, manusia sebagai jenis, sebagai generasi maupun umat manusia secara keseluruhan.
Terkait dari uraian tersebut Allah berfirman dalam Al Qur'an surat Al-Ashr ayat $1-3$ dinyatakan dalam artinya:

"Demi masa sesungguhnya manusia itu benar-benar berada dalam kerugian, kecuali orang-orang yang beriman dan mengajarkan amal shaleh, nasehat menasehati supaya menaati kebenaran dan nasehat menasehati supaya menatapi kesabaran".

Firman tersebut sekaligus menunjukkan bahwa proses pendidikan berpusat pada manusia sebagai sasaran taklif, dan merupakan proses sosial yang menuntut kerja sama masyarakat diberbagai lapangan kehidupan. Isi pertama pendidikan Islam berkaitan dengan sebuah tujuan besar, yaitu beriman karena Allah serta menjalin hubungan individu, masyarakat, dan umat manusia dengan Al Khaliq sehingga kehidupan menjadi bertujuan dan memiliki orientasi yang jelas di jalan benar menuju ridho Allah.

Isi pendidikan Islam selanjutnya ialah amal saleh, saling mengingatkan agar mentaati kebenaran. Isi ini sejalan dengan ilmu yang bertujuan menyingkap hakekat dan mencari kebenaran, dan saling mengingatkan agar menepati kesabaran merupakan inti akhlak yang disebut di dalam Al Qur'an lebih dari seratus kali. Isi pendidikan agama Islam yang terakhir ialah pendidikan sosial, mencakup kerja sama dan menumbuhkan keimanan dan amal saleh serta saling mengingatkan agar menaati kebenaran dan menaati kesabaran.

\section{Pendidikan Keimanan}

Pendidikan agama Islam berwatak rabbani. Watak tersebut menempatkan hubungan antara hamba dan Al Khaliq sebagai isi pertama pendidikan agama Islam. Dengan hubungan tersebut, kehidupan individu akan bermakna, perbuatannya akan bertujuan, peranannya mendorong untuk belajar dan beramal akan tumbuh, akhlaknya menjadi mulia dan jiwanya menjadi bersih, sehingga pada gilirannya akan memiliki kompetensi untuk menjadi khalifah di muka bumi.

Pendidikan rabbani atau pendidikan keimanan tidak sama dengan pendidikan keagamaan serta arti pendidikan kependetaan seperti berlangsung di barat dengan nama religius education. Pendidikan semacam itu tidak ada di dalam kamus agama Islam sebab pendidikan agama Islam mencakup Islam itu sendiri dengan segala konsepnya.

Pendidikan rohani sebagai salah satu dimensi pendidikan agama Islam tidak hanya 
ditempuh melalui hubungan antara hamba dan penciptanya secara langsung tetapi juga melalui interaksi hamba dengan berbagai fenomena alam dan lapangan kehidupan, baik sosial maupun fisik. Dengan kata lain, pendidikan agama Islam memperhatikan pengembangan keimanan tidak hanya melalui perkara gaib fenomena rohaniah, dan peribadatan semata. Kitab alam yang terbuka ini dengan segala fenomenanya serta berbagai ilmu dan praktik kehidupan dapat memperkokoh dan berkaitan dengan fenomena keimanan.

Ayat-ayat Al Qur'an yang menyerukan keimanan sangat bervariasi sejalan dengan bervariasinya lapangan kehidupan itu sendiri. Sebagaimana firma Allah SWT surat AlBaqarah ayat $1-5$, yang artinya:

Alif lam min, kitab (Al Qur'an) ini tidak ada keraguan padanya, petunjuk bagi mereka yang bertaqwa, yaitu mereka yang beriman kepada yang gaib, yang mendirikan shalat, dan menafkahkan sebahagian rezeki yang kamu anugrahkan kepada mereka dan mereka yang beriman kepada kitab yang telah diturunkan kepadamu dan kitab-kitab yang telah diturunkan sebelummu, serta mereka yakin akan adanya kehidupan akhirat. Mereka itulah yang tetap mendapat petunjuk dari Tuhan mereka, dan merekalah orang-orang yang beruntung".

Firman Allah tersebut di atas, menggugah keimanan melalui perkara gaib, ayat-ayat Al Qur'an dan ibadah-ibadah seperti shalat dan zakat.

Harus dicamkan bahwa iman merupakan sumber akhlak yang luhur sebagai wajah sikap taqwa kepada Allah SWT. Akhlak pada gilirannya menuntun manusia untuk menemukan kebenaran dan hakekat, yaitu ilmu, sedangkan ilmu akan menuntun manusia untuk mengerjakan amal shaleh. Jadi, iman merupakan dasar akhlak yang luhur, akhlak merupakan dasar ilmu yang benar, dan ilmu merupakan dasar akal yang saleh. Inilah konstruksi pendidikan Qurani. Setiap komponennya saling terkait secara koordinatif dan kokoh.

\section{Pendidikan Amaliah}

Pendidikan agama Islam memperhatikan aspek amaliah karena manfaatnya yang besar bagi kehidupan di dunia berupa kebaikan dan kebahagiaan bagi individu dan masyarakat. Perhatian tersebut terlihat dalam sabda Rasulullah SAW maupun Firman Allah SWT.

Rasulullah bersabda dengan artinya: "Ya Allah, sesungguhnya aku berlindung kepada-Mu dari ilmu yang tidak bermanfaat".

Dan Allah berfirman pada surat AlBaqarah ayat 2 yang artinya: "Dan orangorang yang beriman serta beramal saleh mereka itu penghuni syurga mereka kekal di dalamnya".

Amal saleh, di samping merupakan tema umum isi pendidikan agama Islam, juga merupakan buah yang baik dari ilmu yang benar, akhlak yang luhur, dan pendidikan sosial yang bertanggung jawab.

Rasulullah SAW, pernah memegang tangan seorang pekerja sebagai penghargaan terhadapnya seraya bersabda: "Inilah tangan yang dicintai Allah dan Rasul-Nya.

Sikap Rasulullah SWA tersebut menunjukkan penghargaan yang amat tinggi terhadap kerja (amal), para pekerja dan pendidikan profesi. Ketinggiannya tampak pada hubungan antara kerja kecintaan Allah serta Rasul terhadapnya.

\section{Pendidikan Ilmiah}

Isi pendidikan agama Islam yang ialah ilmu pengetahuan dimulai dengan keterampilan membaca dan menulis. Sehubungan dengan itu, Allah berfirman pada surat Al-Alaq ayat 1 dan 4 yang artinya "Bacalah dengan (menyebut) nama Tuhanmu yang menciptakan....".

"Yang mengajar (manusia) dengan perantaraan kalam ", lanjutkan dengan pengetahuan manusia yang dimulai dari pengetahuan tentang jiwa manusia sampai kepada lingkungan sosial sepanjang masa dan setiap tempat, kemudian tentang lingkungan fisik fenomena-fenomena alam.

Pandangan agama Islam terhadap ilmu pengetahuan bersifat komprehensif karena lahir dari prinsip kesatuan merupakan aspek penting di dalam konsep alam. Atas dasar itu agama Islam berperan mendorong manusia yang mempelajari setiap pengetahuan yang bermanfaat bagi dirinya, masyarakat, dan semua umat manusia baik dalam lingkungan pengetahuan kesyariatan maupun pengetahuan sosial, kealaman ataupun pengetahuan lainnya.

Pendidikan agama Islam memiliki konsep tentang watak pengetahuan ilmiah dan metode pembahasannya. Islam mengajarkan 
kepada manusia untuk menggunakan akalnya secara maksimal.

\section{Pendidikan Akhlak}

Pendidikan akhlak merupakan bagian besar dari isi pendidikan agama Islam. Posisi ini terlihat dari kedudukan Al Qur'an sebagai refrensi paling penting tentang akhlak bagi kaum muslimin: individu, keluarga, masyarakat dan umat. Akhlak merupakan buah agama Islam yang bermanfaat bagi manusia dan kemanusiaan serta membuat hidup dan kehidupan menjadi baik. Akhlak merupakan alat kontrol psikis dan sosial bagi individu dan masyarakat. Tanpa akhlak manusia tidak akan berbeda dari kumpulan binatang.

Pendidikan akhlak dalam agama Islam yang bersimpul dalam prinsip "berpegang pada kebaikan dan kebajikan serta manjauhi keburukan dxan kemungkaran" berhubungan erat dengan upaya mewujudkan tujuan besar pendidikan agama Islam, yaitu ketaqwaan, ketundukan, dan beribadah kepada Allah. Hubungan ini sebenarnya merupakan hubungan semua isi pendidikan agama Islam.

Sehubungan dengan itu, Allah berfirman dalam Al Qur'an surat Al-Imran ayat 104 yang artinya: " Dan hendaklah ada diantara kamu segolongan umat yang menyeru kepada kebajikan, menyeru kepada yang ma'ruf dan mecegah dari yang mungkar, mereka orang-orang yang beruntung". Maksud dari ayat tersebut, memeiliki harapan, agar umat manusia bersikap taqwa.

Karena itu, menurut Suyuti (1994: 20) mengatakan bahwa taqwa adalah tingkat kualitas yang paling tinggi yang dicapai oleh manusia, sehingga perbuatan taqwa akan dapat menggambarkan kepribadian dan tingkah laku yang ideal seseorang di dalam penghambaannya kepada Allah, juga dalam pergaulan sesama manusia".

Berdasarkan dari pengertian tersebut, maka jelaslah dihadapan kita peranan pendidikan agama Islam adalah mendorong umat untuk bersikap taqwa dengan melalui dari isi yang dimuat pendidikan agama Islam. Karena itu harus dipahami bahwa cara mewujudkan sikap taqwa ternyata memang tidak terlepas dari sekian isi pendidikan agama Islam tersebut di atas.

Agustami (2002: 8) mengemukakan ciri-ciri taqwa sebagai berikut:

1. Beriman kepada Allah, hari kemudian, malaikat-malaikat, kitab-kitab, nabinabi, dan memberikan harta yang dicintainya kepada kaum kerabat, anakanak yatim, orang miskin, musafir dan orang-orang berminta-minta, hamba sahaya, mendirikan shalat, menunaikan zakat, menepati janji apabila berjanji serta sabar dalam kesempitan, penderitaan dan dalam peperangan.

2. Orang-orang yang sabar, yang benar, yang tetap taat, yang menafkahkan hartanya di jalan Allah.

3. Orang-orang yang menafkahkan hartanya baik diwaktu lapang maupun diwaktu sempit, orang yang menahan amarah.

4. Orang-orang yang selalu menegakkkan kebenaran karena Allah, menjadi saksi yang adil.

Allah menciptakan manusia dalam bentuk yang paling sempurna yaitu menjadi orang yang paling bertaqwa, yang dilengkapai dengan akal pikiran serta hati nurani. Inilah perbedaan mendasar antara manusia dan makhluk ciptan-Nya.

Tujuan hidup manusia hanya menyangkut nilai yang di bawahnya yaitu sikap taqwa. Nilai merupakan kualitas yang mencakup bidang yang sangat perlu dibentuk dalam kehidupan manusia itu sendiri. Pendidikan agama Islam menganjurkan kepada manusia agar bersikap baik atau bersikap taqwa dan memelihara tiga hal, yaitu pola perilaku kepada Allah, pola perilaku kepada sesama manusia dan pola perilaku kepada alam.

Tim dosen agama Islam IKIP Makassar (1990: 54) mengemukakan, bahwa perilaku yang baik kepada Allah adalah:

1. Syukur yaitu mengungkapkan rasa syukur kepada Allah atas nikmat yang telah diberikannya, ungkapan rasa syukur dilakukan dengan kata-kata dan perilaku. Ungkapan dalam bentuk kata-kata adalah dengan mengucapkan Hamdalah setiap saat, sedangkan bersyukur dengan perilaku adalah menggunakan nikmat Allah sesuai dengan semestinya. Misalnya menggunakan mata untuk melihat hal-hal yang baik, seperti membaca, mengamati alam dan sebagainya yang mendatangkan manfaat.

2. Bertasbih yaitu mensucikan Allah dengan ucapan, memperbanyak mengucapkan Subhanallah.

3. Istighfar yaitu meminta ampun kepada Allah segala dosa yang pernah diperbuat dengan mengucapkan Astaghfirullahal'adzim. 
4. Mengagungkan

Allah mengucapkan "Allahu Akbar"

dengan

5. Meminta kepada Allah apa saja yang diinginkan dengan mengemukakan keinginan yang diharapkan itu dengan cara sebagaimana dicontohkan oleh Rasulullah".

Selain itu, perilaku manusia terdiri dari perilaku terhadap diri sendiri dan sesama manusia. Perilaku kepada diri sendiri adalah menyayangi diri sendiri dengan menjaga diri sendiri dari perbuatan yang buruk. Bertingkah laku yang baik kepada diri sendiri lebih banyak dilakukan dengan cara menjaga dan memelihara hati agar memiliki perasaan hati selalu ikhlas dan berhati bersih. Membersihkan hati berupa menahan dan mengendalikan keinginan atau dorongan-dorongan hati yang terbawa oleh tarikan keburukan. Hati yang bersih akan dilahirkan ucapan dan perilaku yang baik sebagai gambaran sikap taqwa kepada Allah SWT.

Perilaku yang baik terhadap orang lain merupakan gambaran hasil pengendalian diri sebagai akibat peranan pendidikan agama Islam. Jika hati telah bersih akan muncul pikiran-pikiran yang selalu positif dan melihat orang lain dari sabagai bagian dari dirinya, karena itu akan lahir rasa kasih sayang sebagai dasar hubungan baik antar sesama manusia.

Hubungan atas dasar kasih sayang berkat pendidikan agama Islam, maka akan lahirlah yang dinamakan sikap taqwa. Bahkan karena ketaqwaan seseorang, maka akan memandang alam ini sebagai milik Allah yang wajib disyukurinya dengan cara menggunakan dan mengelola alam sebaik-baiknya agar memberi manfaat bagi manusia sekaligus sebagai bagian sikap taqwa kepada Allah SWT.

Pemanfaatan alam diajarkan Islam adalah pemanfaatan yang didasari sikap tanggung jawab tanpa merusaknya. Alam memberi keuntungan tidak hanya diambil keuntungannya, tetapi juga agar alam tetap utuh dan lestari dengan cara memberikan kesempatan kepada alam untuk membantunya untuk mempercepat pemulihannya kembali.

Berperilaku baik kepada alam berarti menyikapi alam dengan cara memelihara kelestariannya, sebagai wujud sikap taqwa kepada Allah SWT.

Dengan demikian, maka dengan adanya umat Islam melakukan secara baik sesuai dengan ajakan dan peranan pendidikan agama Islam tentu akan terwujud pembentukan sikap taqwa anak di sekolah dasar.

\section{KESIMPULAN \& SARAN}

Berdasarkan uraian karya tulis ilmiah di atas, maka penulis dapat mengemukakan suatu kesimpulan sebagai berikut: Peranan pendidikan agama Islam dalam membentuk sikap taqwa pada anak di sekolah dasar, pada dasarnya diperlukan kesadaran, penghayatan serta pengalaman dari beberapa unsur yang bertalian dengan isi pendidikan agama Islam mengandung keimanan, amaliah, ilmiah, dan pendidikan tentang akhlakul karimah sebagai wujud akibat dari pendidikan agama Islam dengan berfokus unsur-unsur objek kajian tersebut di atas.

Mengingat pentingnya peranan pendidikan agama Islam, maka penulis dapat menyarankan sebagai berikut:

1. Agar penentu kebijakan khususnya Departemen Agama RI, memberi perhatian banyak terhadap upaya peningkatan pendidikan agama Islam dalam rangka terbentuknya sikap taqwa pada anak terutama dikalangan sekolah dasar

2. Agar guru dalam melaksanakan tugasnya selalu memperhatikan peranan pendidikan agama Islam dalam membentuk sikap taqwa anak di sekolah dasar.

\section{DAFTAR PUSTAKA}

Agustami. 2002. Keseimbangan Peningkatan IMTAK dengan Penguatan IPTEK. Jakarta: PT Dian Ariesta.

Ahmad. 1994. Ilmu Pendidikan Dalam Perspektif Islam. Bandung: PT Remaja Rosdakarya.

Arifin. 1999. ISD (Ilmu Sosial Dasar). Bandung: CV Pustaka Setia.

Departemen Agama RI. 1971. Al Qur'an dan Terjemahannya. Jakarta: Yayasan Penyelenggara Penerjemah Al Qur'an.

Hamdani. 1986. Filsafat Pendidikan. Yogyakarta: Kota Kembang.

Hery Noer. 2001. Watak Pendidikan Islam. Jakarta: Friska Agung Insani.

Ngalim. 2002. Ilmu Pendidikan Teoritis dan Praktis. Bandung: PT Rosda Karya.

Slamet. 1983. Metodik Khusus Pendidikan Agama. Malang: Biro Ilmiah Fakultas Tarbiyah IAIN Sunan Ampel. 